\title{
ТОРУЮЧИ ШЛЯХ УКРАЇНСЬКІЙ ЛІНГВІСТИЦІ ЕМОЦІЙ
}

(Сліпецька В. Лінгвістика емоцій: формування i розвиток (історико-теоретичний опис; бібліографічний покажчик) / наук. ред. докт. філол. наук, проф. Т. А. Космеда. Дрогобич: Редакційновидавничий відділ Дрогобицького державного педагогічного університету імені Івана Франка. 2017. 354 с.)

Останнє десятиліття в українському мовознавстві все частіше розробляються наукові проблеми й напрями, що стосуються низки питань взаємозв'язку лінгвістики з іншими суміжними науками, якот: літературознавство, психологія, релігієзнавство, правознавство тощо. I саме міждисциплінарність та синтетичність $€$ їхніми визначальними й характерними рисами. На тлі вже доволі добре розроблених в українському мовознавстві синтетичних наук своєрідною цілиною є лінгвоемоціологія, що формується на межі різних і нелінгвістичних, передовсім психології та філософії, і лінгвістичних наук: лінгвофілософії, психолінгвістики, лінгвоаксіології, лінгвокультурології, лінгвокогнітології, лінгвоконцептології, етнолінгвістики, гендерної лінгвістики, теорії та історії мовознавства, зіставної та порівняльно-типологічної лінгвістики.

Рецензована синкретична праця, що поєднує історико-теоретичний опис матеріалу з бібліографічним покажчиком, має на меті репрезентувати появу в українському мовознавстві нового напряму - лінгвоемоціології (лінгвістики емоцій), що, окреслившись у лоні психолінгвістики й поступово виокремившись з неї, попри те, що на сьогодні має значний теоретичний доробок, досі не була визнана як самостійна мовознавча дисципліна. Власне, метою цього видання і є систематизація бібліографії праць, що репрезентують наукові парадигми дослідження засобів вербалізації емоцій у споріднених і неспоріднених лінгвокультурах з попередньо здійсненим аналітичним оглядом генези й розвитку лінгвістики емоцій, історіографічний огляд праць із проблем лінгвістики емоцій, передовсім української. Дослідниця змоделювала й діаграму активності досліджень 3 лінгвоемоціології, що унаочнює матеріал.

Зауважмо, що останнім часом в українському мовознавстві, хоч і не рясно, однак з'являються нові бібліографічні покажчики, які 
укладені не лише за принципом персоналій відомих українських мовознавців, наприклад, О. Олексенко (Харків, 2014), Т. Космеди (Познань - Дрогобич, 2017), але й за тематичною ознакою. Зокрема, до безперечних надбань останніх років можемо віднести праці Марії Скаб «Мова і релігія: бібліографічний покажчик: навчальнометодичний посібник для студентів філологічного та теологічного факультетів» (Чернівці, 2016), Мар'яна Скаба «Мовні засоби і способи найменування та позначення адресата мовлення» (Чернівці, 2020), Д. Пилипчука «Словники української мови: 1596-2018» (Київ, 2020). Цінність таких видань передовсім у іх практичному застосуванні, адже вони скеровують читача в ракурсі систематизації наукової літератури, пришвидшують пошук потрібних джерел, загалом полегшують орієнтацію в тій чи тій науковій царині.

3 огляду на сказане актуальність виходу рецензованої праці цілком очевидна, адже вона, по-перше, унаочнює наявність великого масиву літератури, що прямо чи опосередковано стосується лінгвоемоціології, по-друге, суттєво скоординовує роботу тих науковців, які прагнуть заповнити лінгвістичні лакуни.

До видання абсолютно доцільно вміщено жанровий (автореферати дисертацій, монографії, статті з лінгвоемоціології, що демонструє iii становлення як самостійного лінгвістичного напряму (під час висвітлення цієї проблеми авторка зосередила увагу на публікаціях в наукових збірниках, матеріалах науково-практичних конференцій, фахових виданнях та науково-методичних журналах)), хронологічний (починаючи з 1948 до 2017 року) та алфавітний покажчики (загалом подано понад 600 бібліографічних позицій). Окрім того, власне покажчику передує розділ з теоретичною викладкою важливих питань лінгвістики емоцій, серед яких простежуємо аналіз передумов становлення лінгвоемоціології, огляд етапів ії розвитку, актуальні філософські теорії, пов'язані з нею; психолінгвістичні дослідження як база теоретичного обгрунтування; указівка на внесок відомих зарубіжних і вітчизняних учених (В. Вундта, О. Потебні, Ш. Баллі, Л. Булаховського, В. Шаховського, Т. Космеди та ін.) у розвиток теорії лінгвоемоціології.

В. Сліпецька торкається питань методологічного підгрунтя лінгвоемоціолінгвістичних досліджень, а саме в загальних рисах описує розширення метамови цього наукового напряму та його актуальні 
дослідницькі методики; простежує фіксацію ключових термінів лінгвоемоціології в новітніх лінгвістичних словниках, зокрема залучивши для цього чотиритомний «Словник сучасної лінгвістики: поняття і терміни» А. Загнітка (2012), намагається розкрити особливості лінгвістичного вивчення емоції страху, емоцій конфлікту, специфіку феномену мовчання в конфліктних ситуаціях та ін.

Попри те, що в окремих місцях простежуємо фрагментарність викладу теоретичного матеріалу (але ж повний виклад методологічних засад теорії і не передбачено жанром бібліографічного покажчика), це не впливає на загалом позитивне враження від видання. За своєю структурою та змістом праця є цілком виваженою і такою, що належить, як наголошувалося, до робіт гібридного типу.

Зрозуміло, що сучасна наука динамічна, як і сама мова, жодне лексикографічне джерело не встигає за ії розвитком, як, очевидно, і будь-який бібліографічний покажчик ніколи не буде повним, оскільки за період його укладання з'являються нові праці, що виявляються поза його межами. Тому, очевидно, до рецензованого видання не увійшла низка дисертаційних досліджень, наприклад Ю. Заморської (Київ, 2014), Н. Коловоротної (Харків, 2014), які стосуються лінгвістичного аналізу феномену мовчання; В. Яригіної (Харків, 2012), де на матеріалі українських проповідей здійснено дослідження мовних засобів вираження експресії та ін.; деякі монографії, наприклад, Н. Бойко «Українська експресивна лексика: семантичний, лексикографічний і функціональний аспекти» (Ніжин, 2005), С. Воркачова «Счастье как лингвокультурный концепт» (Москва, 2007) та ін., а також низка статей із зазначеної проблематики представників харківської філологічної школи, наприклад, Н. Піддубної, Я. Сазонової та ін.

Сподіваємося, що наступне видання фрагментарної монографіїпокажчика буде більш повним й міститиме ті праці, що вийшли після 2017 року. Без сумніву, це видання потрібне науковцям, викладачам, магістрам та студентам, а згодом укладачка доповнить його, зокрема, і своїми працями.

\section{ЛІТЕРАТУРА}

1. Воркачев, С. Г. (2007). Счастье как тингвокультурный кониепт. Москва: Гнозис. 2. Загнітко, А. П. (2012). Словник сучасної лінгвістики: поняття і терміни. Донецьк: ДонНУ. 3. Заморська, Ю. В. (2014). Комунікативне мовчання в японській лінгвокультурі (на матеріалі творів Я. Кавабата). (Автореф. ... канд. філол. наук). 
Київ: НАН України, Ін-т сходознавства ім. А. Ю. Кримського. 4. Коловоротна, Н. Д. (2014). Вербалізація концепту “мовчання” в художньому дискурсивному просторі української мови. (Дис. ... канд. філол. наук). Харків: ХНПУ імені Г. С. Сковороди. 5. Космеда, Т. А. (2017). Біобібліографічний покажчик. Познань: Коло (Дрогобич). 6. Олексенко Олена Андріївна. Бібліографічний покажчик (2014). Харків. 7. Пилипчук, Д. (2020). Словники української мови: 1596-2018. Київ: ВЦ «Просвіта». 8. Піддубна, Н. В. (2013) Вербалізація концепту “мовчання” в художньому тексті релігійної тематики: лінгвокреативна спроможність І. Франка (на матеріалі поеми «Мойсей»). Лінгвістичні дослідження, 35, 168-172. 9. Піддубна, Н. В. (2015). Вербалізація релігійних почуттів у листах Тараса Шевченка. Лінгвістичні дослідження, 39, 97-103. 10. Сазонова, Я. Ю., \& Захарова, К. В. (2016). Ідентифікація суб’єкта-джерела страху лінгвістичними засобами означеності / неозначеності. Лінгвістичні дослідження, 44, 122-129. 11. Скаб, М. (Укл.). (2016). Мова і релігія: бібліограбічний покажчик. Чернівці: ВД «Родовід». 12. Скаб, М. (2020). Мовні засоби і способи найменування та позначення адресата мовлення. Чернівці. 13. Яригіна, В. В. (2012). Мовні засоби вираження експресії в жанрі сучасної проповіді. (Дис. ... канд. філол. наук). Харків: ХНПУ імені Г. С. Сковороди.

\section{REFERENCES}

1. Vorkachev, S. G. (2007). Schastye kak lingvokulturnyy kontsept [Happiness as a linguocultural concept]. Moskva: Gnozis [in Russian]. 2. Zahnitko, A. P. (2012). Slovnyk suchasnoi linhvistyky: poniattia $i$ terminy [Dictionary of modern linguistics: concepts and terms]. Donetsk: DonNU [in Ukrainian]. 3. Zamorska, Yu. V. (2014). Komunikatyvne movchannia v yaponskii linhvokulturi (na materiali tvoriv Ya. Kavabata) [Communicative silence in Japanese linguistic culture (based on the works of J. Kawabata). Extended abstract of candidate's thesis. Kyiv: NAN Ukrainy, In-t skhodoznavstva im. A. Yu. Krymskoho [in Ukrainian]. 4. Kolovorotna, N. D. (2014). Verbalizatsiia kontseptu "movchannia" v khudozhnomu dyskursyvnomu prostori ukrainskoi movy [Verbalization of the concept of "silence" in the artistic discursive space of the Ukrainian language]. Candidate's thesis. Kharkiv: KhNPU imeni H. S. Skovorody [in Ukrainian]. 5. Kosmeda, T. A. (2017). Biobibliohrafichnyi pokazhchyk [Biobibliographic index]. Poznan: Kolo (Drohobych) [in Ukrainian]. 6. Oleksenko Olena Andriivna. Bibliohrafichnyi pokazhchyk (2014) [Oleksenko Olena Andriivna. Bibliographic index]. Kharkiv [in Ukrainian]. 7. Pylypchuk, D. (2020). Slovnyky ukrainskoi movy: 1596-2018 [Dictionaries of the Ukrainian language: 1596-2018]. Kyiv: VTs «Prosvita» [in Ukrainian]. 8. Piddubna, N. V. (2013) Verbalizatsiia kontseptu "movchannia" v khudozhnomu teksti relihiinoi tematyky: linhvokreatyvna spromozhnist I. Franka (na materiali poemy «Moisei») [Verbalization of the concept of "silence" in the artistic text of religious themes: the linguo-creative ability of Ivan Franko (based on the poem «Moses»)]. Linhvistychni doslidzhennia - Linguistic research, 35, 168-172 [in Ukrainian]. 9. Piddubna, N. V. (2015). Verbalizatsiia relihiinykh pochuttiv u lystakh Tarasa Shevchenka [Verbalization of religious feelings in Taras Shevchenko's letters]. Linhvistychni doslidzhennia - Linguistic research, 39, 97-103 [in Ukrainian]. 10. Sazonova, Ya. Yu., \& Zakharova, K. V. (2016). Identyfikatsiia subiekta-dzherela strakhu linhvistychnymy zasobamy oznachenosti / neoznachenosti [Identification of the subject "fear" by linguistic means of significance / uncertainty]. Linhvistychni 
doslidzhennia - Linguistic research, 44, 122-129 [in Ukrainian]. 11. Skab, M. (Ed.). (2016). Mova i relihiia: bibliohrafichnyi pokazhchyk [Language and religion: a bibliographic index]. Chernivtsi: VD «Rodovid». 12. Skab, M. (2020). Movni zasoby i sposoby naimenuvannia ta poznachennia adresata movlennia [Language means and methods of nomination and designation of the speech addressee]. Chernivtsi [in Ukrainian]. 13. Yaryhina, V. V. (2012). Movni zasoby vyrazhennia ekspresii $\mathrm{v}$ zhanri suchasnoi propovidi [Linguistic means of expression in the genre of modern preaching]. Candidate's thesis. Kharkiv: KhNPU imeni H. S. Skovorody [in Ukrainian].

Піддубна Наталія Віталіївна - доктор філологічних наук, доцент, доцент кафедри української мови, Харківський національний педагогічний університет імені Г. С. Сковороди; вул. Валентинівська, 2, м. Харків, 61168, Україна.

Tel.: +38 097-43-96-510

E-mail : piddubnan71@gmail.com

http://orcid.org/0000-0003-0331-0496

Piddubna Nataliia Vitaliivna - Doctor of Philological Sciences, Docent, Associate Professor at the Department of Ukrainian Language, H. S. Skovoroda Kharkiv National Pedagogical University; 2 Valentynivska Str., Kharkiv, 61168, Ukraine.

Надійшла до редакції 8 вересня 2021 року

\section{CITATION}

ДСТУ 8302:2015: Піддубна Н. В. Торуючи шлях українській лінгвістиці емоцій. Рец. на: Сліпецька В. Лінгвістика емоцій: формування і розвиток (історикотеоретичний опис; бібліографічний покажчик) / наук.ред. докт. філол. наук, проф. Т. А. Космеда. Дрогобич: Редакційно-видавничий відділ Дрогобицького державного педагогічного університету імені Івана Франка. 2017. 354 с. Лінгвістичні дослідження: 3б. наук. пр. Харк. нац. пед. ун-ту імені Г. С. Сковороди. Харків, 2021. Вип. 55. С. 180 184. DOI: https://doi.org/10.34142/23127546.2021.55.17

AРА: Піддубна, Н. В. (2021). Торуючи шлях українській лінгвістиці емоцій. Рец. на: Сліпецька В. Лінгвістика емоцій: формування і розвиток (історико-теоретичний опис; бібліографічний покажчик) / наук.ред. докт. філол. наук, проф. Т. А. Космеда. Дрогобич: Редакційно-видавничий відділ Дрогобицького державного педагогічного університету імені Івана Франка. 2017. 354 с. Лінгвістичні дослідження, 55, 180-184. DOI: https://doi.org/10.34142/23127546.2021.55.17 